\title{
Evaluation of the Relationship between Serum Vitamin D and Morbidity and Mortality in Patients with COVID-19
}

Hamid Khederlou ${ }^{1}$, Ahmadreza Rasouli ${ }^{2,3}$, Razieh Anari ${ }^{4}$, Fahime Moeini ${ }^{5}$, Samaneh Parsa ${ }^{6}$, Narges Sadeghi ${ }^{7,8}$ and Narjes Zarei jalalabadi 6* $^{*}$

${ }^{1}$ Resident of Cardiology, Tehran Heart Center, Tehran University of Medical Sciences, Tehran, Iran.

${ }^{2}$ Department of Nutrition, School of Health, Qazvin University of Medical Sciences, Qazvin, Iran.

${ }^{3}$ Student Research Committee, School of Health, Qazvin University of Medical Sciences, Qazvin, Iran.

${ }^{4}$ Ph.D. Candidate in Nutrition Research, Department of Nutrition Research, National Nutrition and Food Technology Research, Institute (NNFTRI), Shahid Beheshti University of Medical Sciences (SBMU), Tehran, Iran.

${ }^{5}$ Department of Biostatistics, School of Medicine, Zanjan University of Medical Sciences, Zanjan, Iran.

${ }^{6}$ Assistant Professor of Internal Medicine, Department of Internal Medicine, Imam Khomeini Hospital, Tehran University of Medical Sciences, Tehran, Iran.

${ }^{7}$ Student Research Committee, Ahvaz Jundishapur University of Medical Sciences, Ahvaz, Iran.

${ }^{8}$ Department of Nutrition, School of Allied Medical Science, Ahvaz Jundishapur University of Medical Sciences, Ahvaz, Iran

*Corresponding Author: Narjes Zarei jalalabadi, Assistant Professor of Internal Medicine, Department of Internal Medicine, Imam Khomeini Hospital, Tehran University of Medical Sciences, Tehran, Iran.

Received date: June 19, 2021; Accepted date: July 29, 2021; Published date: August 11, 2021

Citation: Narjes Z. jalalabadi, Hamid Khederlou, Ahmadreza Rasouli, Razieh Anari, Fahime Moeini, et al. (2021). Evaluation of the Relationship between Serum Vitamin D and Morbidity and Mortality in Patients with COVID-19. J Thoracic Disease and Cardiothoracic Surgery, 2(3);

DOI:10.31579/2693-2156/026

Copyright: (C) 2021, Narjes Zarei jalalabadi. This is an open access article distributed under the Creative Commons Attribution License, which permits unrestricted use, distribution, and reproduction in any medium, provided the original work is properly cited.

\section{Abstract}

Background: The COVID-19 can cause serious life-threatening complications. Vitamin D deficiency has been proposed to mediate the disease by some studies, however, there is a lack of sufficient data.

Methods: In this descriptive-analytical study, 72 Iranian adult patients with COVID-19 were examined. At the beginning of hospitalization, serum levels of vitamin $\mathrm{D}$ were checked and patients were divided into four groups as vitamin D above normal, normal, insufficient, or deficient. The prognosis of patients has been evaluated based on serum levels of vitamin D and other underlying factors.

Results: Only $30 \%$ of patients had normal vitamin D concentrations. Vitamin D status was associated with COVID-19 complications, but not with underlying diseases. In the multivariable logistic regression, COVID-19 prognosis was associated with being male, length of stay in an intensive care unit (ICU), need for intubation, acute respiratory disease syndrome (ARDS), and myocarditis. The serum vitamin D correlated with COVID-19 complications including ARDS, QT length, the requirement to $\mathrm{ICU}$, and intubation.

Conclusion: This study showed a mediating role for vitamin D in COVID-19 complications and identified the frequent complications in these patients and contributing variables exaggerating prognosis for health authorities to properly manage COVID-19 in hospitals. Further relevant examinations are highly encouraged.

Keywords: 2019 novel-coronavirus; calcidiol; COVID-19; prognosis; sars-cov; vitamin d; coronaviridae; Brazil; WHO; acute respiratory disease syndrome; thrombomodulin 


\section{Background}

Coronaviruses are a type of RNA virus from the Coronaviridae $(\mathrm{CoV})$ family that is widely distributed in mammals such as humans [1]. Family's $\mathrm{CoV}$ has caused severe acute respiratory distress syndrome (SARS-CoV) which started in 2002 and Middle East Respiratory Syndrome (MERS$\mathrm{CoV}$ ) which started in 2012 in more than 10,000 people [2, 3].

Since December 2019, the outbreak of viral pneumonia was observed in Wuhan, Hubei Province, China. After identifying the virus, the pathogen of this pneumonia was initially called the 2019 novel-coronavirus (2019$\mathrm{nCoV}$ ) [4]. The most common manifestations of 2019-nCoV are fever, nonproductive cough, myalgia, fatigue, weakness, diarrhea, dyspnea, anosmia, and hemoptysis [1]. Most people who become infected are asymptomatic and carrier, but it can cause serious side effects and lifethreatening complications, including acute respiratory distress syndrome, pneumonia, myocarditis, acute kidney injury, and failure of other organs [5]. Respiratory failure is the most common dangerous complication of 2019-nCoV [6]. The most important risk factors for the 2019 coronavirus disease (COVID-19) progression are aging, immunodeficiency, and past underlying disease. Recent epidemiologic evidence suggested that vitamin D deficiency might be another potential risk factor for the disease [7].

Vitamin D is a fat-soluble vitamin produced in the skin after reaction of ultraviolet (UV) with 7-dehydrocholesterol and its biologically active form, 1,25-dihydroxy vitamin D, is finally made in the kidney [8]. Recent studies have shown that vitamin $\mathrm{D}$, in addition to its role in bone mineralization and calcium transportation in the gut, has several receptors in the vascular endothelium, smooth muscle, and heart, as well as epithelium tissue of the airways, and it is effective in inflammatory processes [8-11]. Therefore, vitamin D is probably effective in the progression and severity of inflammatory and infectious diseases. However, there is scarce evidence regarding the impact of vitamin D status on COVID-19 incidence and mortality. Ecological studies from European countries supposed an inverse association between vitamin D status and COVID-19 incidence and mortality [12, 13]. However, observation of high mortality rates from COVID-19 in sunny countries like Brazil with relatively lower vitamin D deficiency (28\%) is debatable [14].

Due to the high prevalence of 2019-nCoV, WHO declared the disease as a pandemic situation in 2020, and also its significant morbidity and mortality have imposed a huge cost on the health care system of many countries; therefore, identification of the most important risk factors engaged in initiation and treatment of this disease can be of great help to the health of individuals and societies. Therefore, this study was conducted to investigate the relationship between serum vitamin D levels and other mediating factors and COVID prognosis among patients with 2019-nCoV.

\section{Methods}

Study design: This was a hospital-based descriptive-analytical study. The study design was reviewed and approved by the Ethics Committee of Tehran University of Medical Sciences (Ethics code: IR.TUMS.VCR.REC.1399.421; 27 May 2020).

Subjects: After obtaining patients' compliance through written consents, 72 adult patients with the 2019-nCoV diagnosis were subsequently recruited from Imam Khomeini hospital, one of the central hospitals for corona cases in Tehran metropolitan, Iran. Data was collected between 20 July 2020 and 27 August 2020.

2019-nCoV diagnosis: Suspected patients having complications like nonproductive cough, fever, dyspnea, and diarrhea were confirmed to have 2019-nCoV infection using RT-PCR and Chest CT scan tests. Patients with negative CT results were excluded from the study.

Data Collection: A checklist, including demographic data and disease history (having any underlying disease), was fulfilled for each patient. Venous blood samples were drawn after admission and were sent to the hospital's laboratory to assess the serum concentration of vitamin D (Calcidiol). Immunoassay technique via liquid chromatography-tandem mass spectrometry (LC-MS/MS) was utilized to measure serum vitamin $\mathrm{D}$ and patients were divided into four groups based on their serum vitamin D concentrations: above normal $(>50 \mathrm{ng} / \mathrm{mL})$, normal $(30-50 \mathrm{ng} / \mathrm{mL})$, insufficient $(10-29 \mathrm{ng} / \mathrm{mL})$, and vitamin D deficiency $(<10 \mathrm{ng} / \mathrm{mL})(15)$. The patient prognosis (as discharge or death), length of hospitalization, ward of hospitalization (medical ward or intensive care unit [ICU]), response to treatment based on $\mathrm{SPO} 2$ and requirement of oxygenation with reserve bag-mask, existence, and type of life-threatening complications (including pneumonia, myocarditis, myocardial infarction [MI], sepsis, acute respiratory disease syndrome [ARDS], acute kidney injury $[\mathrm{AKI}]$, deep vein thrombosis [DVT], convulsion, fraction of inspired oxygen [FIO2], and prolonged QT wave) and transfer to ICU were recorded through a checklist.

Statistical Analysis: Finally, the obtained data were entered into SPSS software (version 25.0, IBM, NY, USA) and the relationship between serum levels of vitamin D and other relevant data for the prognosis of the studied patients was analyzed using descriptive statistical methods as well as logistic regression method. At all statistical stages, a significance level of 0.05 was the criterion for statistical judgments.

\section{Results}

In this study, 72 patients with Covid-19 were examined. The mean age of patients was 56.69 years old (Minimum: 28, Maximum: 85 years) and $63.9 \%$ were male. (Table 1) presents the main characteristics of the studied population in detail.

\begin{tabular}{|l|l|l|}
\hline Variable & Value $(\mathbf{n}=\mathbf{7 2})$ & $\boldsymbol{p}$-value \\
\hline Sex & $26(36.1 \%)$ & \\
Female & $46(63.9 \%)$ & 0.634 \\
Male & $10(13.9 \%)$ & \\
\hline Underlying disease & $62(86.1 \%)$ & 0.508 \\
No & & \\
Yes & $9(12.5 \%)$ & \\
\hline Type of underlying disease & $17(23.6 \%)$ & 0.489 \\
No & $26(36.1 \%)$ & \\
Heart Disease & $20(27.8 \%)$ & \\
Non- Heart Disease & & \\
Both Heart and Non- Heart Disease & & \\
\hline
\end{tabular}




\begin{tabular}{|c|c|c|}
\hline $\begin{array}{l}\text { Needing to ICU } \\
\text { No } \\
\text { Yes }\end{array}$ & $\begin{array}{l}52(72.2 \%) \\
20(27.8 \%)\end{array}$ & $0.001^{*}$ \\
\hline $\begin{array}{l}\text { Needing to FIO2 } \\
\text { No } \\
\text { Yes }\end{array}$ & $\begin{array}{l}22(30.6 \%) \\
50(69.4 \%)\end{array}$ & $0.041^{*}$ \\
\hline $\begin{array}{l}\text { Needing to Intubation } \\
\text { No } \\
\text { Yes }\end{array}$ & $\begin{array}{l}66(91.7 \%) \\
6(8.3 \%)\end{array}$ & $<0.005^{*}$ \\
\hline $\begin{array}{l}\text { Having Complication } \\
\text { No } \\
\text { Yes }\end{array}$ & $\begin{array}{l}41(56.9 \%) \\
31(43.1)\end{array}$ & $0.018 *$ \\
\hline $\begin{array}{l}\text { Pneumonia } \\
\text { No } \\
\text { Yes }\end{array}$ & $\begin{array}{l}59(81.9 \%) \\
13(18.1 \%) \\
\end{array}$ & 0.710 \\
\hline $\begin{array}{l}\text { ARDS } \\
\text { No } \\
\text { Yes }\end{array}$ & $\begin{array}{l}65(90.3 \%) \\
7(9.7 \%)\end{array}$ & $0.005^{*}$ \\
\hline $\begin{array}{l}\text { Sepsis } \\
\text { No } \\
\text { Yes }\end{array}$ & $\begin{array}{l}65(90.3 \%) \\
7(9.7 \%) \\
\end{array}$ & 0.499 \\
\hline $\begin{array}{l}\text { AKI } \\
\text { No } \\
\text { Yes }\end{array}$ & $\begin{array}{l}60(83.3 \%) \\
12(16.7 \%)\end{array}$ & 0.645 \\
\hline $\begin{array}{l}\text { Myocarditis } \\
\text { No } \\
\text { Yes } \\
\end{array}$ & $\begin{array}{l}70(97.2 \%) \\
2(2.8 \%) \\
\end{array}$ & $0.005^{*}$ \\
\hline $\begin{array}{l}\text { DVT } \\
\text { No } \\
\text { Yes }\end{array}$ & $\begin{array}{l}71(98.6 \%) \\
1(1.4 \%)\end{array}$ & 0.807 \\
\hline $\begin{array}{l}\text { Seizures } \\
\text { No } \\
\text { Yes }\end{array}$ & $\begin{array}{l}71(98.6 \%) \\
1(1.4 \%)\end{array}$ & 0.807 \\
\hline $\begin{array}{l}\text { Complications of QT } \\
\text { No } \\
\text { Yes }\end{array}$ & $\begin{array}{l}70(97.2 \%) \\
2(2.8 \%)\end{array}$ & 0.728 \\
\hline $\begin{array}{l}\text { MI } \\
\text { No } \\
\text { Yes }\end{array}$ & $\begin{array}{l}71(98.6 \%) \\
1(1.4 \%) \\
\end{array}$ & $<0.005^{*}$ \\
\hline $\begin{array}{l}\text { Vitamin D Status } \\
\text { Deficient } \\
\text { Insufficient } \\
\text { Normal } \\
\text { Above normal }\end{array}$ & $\begin{array}{l}4(5.6 \%) \\
40(55.6 \%) \\
22(30.6 \%) \\
6(8.3 \%)\end{array}$ & $0.046^{*}$ \\
\hline Age (year) & $56.69 \pm 15.13$ & $0.003 *$ \\
\hline Serum vitamin D (ng/mL) & $27.05 \pm 13.30$ & $0.031 *$ \\
\hline Length of hospitalization (day) & $8.56 \pm 6.08$ & 0.079 \\
\hline Length of stay in ICU (day) & $2.18 \pm 4.67$ & $<0.005^{*}$ \\
\hline
\end{tabular}

FIO2: Fraction of Inspired Oxygen, ARDS: Acute Respiratory Disease Syndrome, AKI: Acute Kidney Injury, DVT: Deep Vein Thrombosis, MI: Myocardial Infarction.

$P<0.05$ is significant. $8.56 \pm 6.08$

Table 1: Characteristics of studied patients and their relation to the final prognosis.

Mean serum vitamin D was $27.05 \mathrm{ng} / \mathrm{mL}$ (SD: 13.30) and only one-third of participants had normal serum vitamin D. In this study participants 68 patients $(94.4 \%)$ were discharged and 4 patients $(5.6 \%)$ died. The most prevalent complication among these patients was Pneumonia (14.9\%) and AKI (13.8\%). Median and Mean of serum vitamin D concentration at recruitment was lower in patients who subsequently finally dead from 
COVID-19 infection than discharged participants (14.50 vs. 24.65, Mean: 14.75 vs. $27.05 \mathrm{ng} / \mathrm{mL}$; $=0.040$ ).

COVID-19 prognosis was predicted univariably $(\mathrm{OR}=2.78,95 \% \mathrm{CI}$ : $0.51-15.26, p=0.24)$, and after adjustment for covariates, including age, sex, length of hospitalization (day), requirement to ICU, length of stay in ICU (day), requirement to FIO2, requirement to intubation, and having a complication (Binary logistic regression, Forward manner). Exposures that predicted COVID-19 prognosis in the multivariable logistic regression were male sex $(\mathrm{OR}=1.21 ; 95 \% \mathrm{CI}=1.01-1.45$; $\mathrm{p}$-value=0.039), length of stay in ICU (day) $(O R=1.23 ; 95 \%$ CI $=1.05-1.43$; value $=0.011)$, need to intubation $(\mathrm{OR}=7.07 ; 95 \% \mathrm{CI}=5.12-82.58 ; \mathrm{p}$ value $=0.052)$, ARDS $(\mathrm{OR}=9.31 ; 95 \% \mathrm{CI}=0.922-94.05 ; \mathrm{p}$-value $=0.059)$, and myocarditis $(\mathrm{OR}=8.02 ; 95 \% \mathrm{CI}=1.11-45.01 ; \mathrm{p}$-value $=0.027)$ (Table 2).

\begin{tabular}{|l|l|l|}
\hline Variable & $\mathbf{r}$ & $\boldsymbol{p}$-value \\
\hline Age (year) & 0.34 & $0.004^{*}$ \\
\hline Sex & 0.27 & 0.164 \\
\hline Length of hospitalization (day) & 0.56 & 0.189 \\
\hline Length of stay in ICU (day) & 0.51 & 0.058 \\
\hline Underlying disease & 0.15 & 0.672 \\
\hline Type of underlying disease & 0.41 & 0.197 \\
\hline Needing to ICU & 0.37 & $0.021^{*}$ \\
\hline Needing to FIO2 & 0.42 & $0.005^{*}$ \\
\hline Needing to Intubation & 0.23 & 0.282 \\
\hline Having a Complication & 0.31 & 0.070 \\
\hline Pneumonia & 0.16 & 0.600 \\
\hline ARDS & 0.35 & $0.033^{*}$ \\
\hline Sepsis & 0.31 & 0.073 \\
\hline AKI & 0.17 & 0.549 \\
\hline Myocarditis & 0.15 & 0.649 \\
\hline DVT & 0.11 & 0.847 \\
\hline Seizures & 0.11 & 0.847 \\
\hline Complications of QT & 0.35 & $0.031^{*}$ \\
\hline MI & 0.11 & 0.847 \\
\hline
\end{tabular}

FIO2: Fraction of Inspired Oxygen, ARDS: Acute Respiratory Disease Syndrome, AKI: Acute Kidney Injury, DVT: Deep Vein Thrombosis, MI: Myocardial Infarction.

Phi, Cramer's V, Contingency Coefficient, Kendall's tau-b, Kendall's tau-c, Spearman Correlation, Pearson's Correlation tests were used for analysis. $\mathrm{P}<0.05$ was significant.

\section{Table 2: Correlation between serum vitamin D and demographic and clinical variables.}

When participants were categorized into vitamin $\mathrm{D}$ deficiency $(<10$ $\mathrm{ng} / \mathrm{mL})$, insufficiency (10-29 $\mathrm{ng} / \mathrm{mL})$, normal $(30-50 \mathrm{ng} / \mathrm{mL})$ and above normal $(>50 \mathrm{ng} / \mathrm{mL})$, the pattern of results was similar to those observed with serum levels of vitamin $\mathrm{D}$ entered numerically and as a continuous variable (univariable $\mathrm{OR}=2.78,95 \% \mathrm{CI}=0.51-15.26, \mathrm{p}=0.24$; adjusted $\mathrm{p}=0.95)$.

As Table 2 demonstrates, serum vitamin D was an only correlation with ARDS, QT length, the requirement to ICU, and intubation.

\section{Discussion}

The widespread of the novel COVID around the world and a great deal of hospitalization with numerous culprits raised concerns to distinguish the underlying contributing factors, especially those affecting the severity and prognosis of the disease. Due to the infectious nature of the disease, identification of the underlying factors mediating the immunity response was the core of many investigations. Some studies have proposed that low circulatory vitamin D has been correlated to SARS-CoV-2 infection susceptibility and severity $[16,17]$. For example, a recent cohort in Switzerland on elderly patients demonstrated a lower serum vitamin D in PCR-positive cases over 70 years old [16]. Vitamin D deficiency has been suggested as a COVID-19 mediator because of its significant role in innate immune regulation $[18,19]$, its modulatory effects on inflammatory responses to infections, and the existence of several vitamin D receptors in different tissues and organs from airways to the heart, especially in leucocytes $[8-11,20]$. vitamin D also counteracts tumor necrosis factor $(T N F)$, Low-density lipoprotein $(L D L)$, and other inflammatory mediators by reducing the expression of CD40 in inflammatory cells, downregulation of tissue factor, and up-regulation of thrombomodulin in monocyte cells [21].

Although some reviews have proposed some mediating roles for vitamin D in COVID-19 morbidity [18, 19], there is a lack of sufficient clinical data regarding the association of serum vitamin D with COVID-19 prognosis. A small study in the US reported that patients admitted to ICU had probably higher vitamin D deficiency compared to those admitted to medical wards $(84.6 \%$ versus $57.1 \%)(22)$. According to our results, poor vitamin D status was associated highly with the length of stay in ICU and after that with ICU admission, needing to FIO2, ARDS, and QT length, but not with death prognosis. Therefore, vitamin D status may indirectly contribute to prognosis in association with ARDS, QT length, and the requirement to ICU and intubation. 
The current investigation demonstrated that COVID prognosis was strongly correlated to being male, ARDS, myocarditis, ICU requirement, need to intubation and length of stay in ICU, and Pneumonia (14.9\%) and AKI $(13.8 \%)$ were the most prevalent complications in our studied patients. These results were in accordance with previous findings implying that COVID-19 was mostly accompanied by pneumonia, ARDS leading to ICU admission, and multi-organ failure [23]. Previous studies proposed age as a contributing factor in COVID mortality [7], we also observed that older patients had 24\% higher COVID-19 prognosis. Also, we observed that female had better COVID prognosis, this could be due to lower ACE2 expression in males than in females which influence the susceptibility to death from COVID-19 [24]. As our results showed, ARDS was a prevalent complication in COVID patients. A meta-analysis of 25 trials revealed that vitamin D supplementation could reduce the risk of acute respiratory infections in all patients, but mostly in those with serum vitamin $\mathrm{D}<50 \mathrm{nmol} / \mathrm{L}(20 \mathrm{ng} / \mathrm{mL})$ [25]. On the other hand, another investigation showed no association between serum vitamin $\mathrm{D}$ and increased oxygen requirements, CRP levels, or co-morbidities [17]. Serum vitamin D was correlated to ARDS, length of stay in ICU, the requirement to ICU, length of QT, and FIO2 in our subjects.

The current study had several strengths. It was the first study that assessed the association between vitamin D status and COVID-19 prognosis, specifically in Iran, a country with rather high vitamin D deficiency and moderate COVID victims. Predicting the COVID-19 prognosis in hospitalized patients using some clinical data was another achievement of this study. Also, the investigation clarified the strongly correlated factors to COVID prognosis, i.e. age, ARDS, myocarditis, MI, intensive care requirement, and length of stay in ICU in the studied population.

This study faced some limitations. Due to the cross-sectional design of this investigation, we could not distinguish the cause-effect relationship between vitamin $\mathrm{D}$ status and disease initiation. Also, some health conditions and drugs may affect both vitamin D status and disease severity. Lack of anthropometric and inflammatory measures were other limitations. These factors restrict the generalization of our findings.

\section{Conclusion}

To conclude, based on our results, vitamin D participates in COVID-19 complications and possibly in its prognosis. Awareness of the frequent complications in patients having COVID in addition to predicting variables could help health professionals and authorities to consider the proper facilities and the best approaches to manage COVID-19 in hospitals. Further examinations with greater sample size, longer duration, and inclusion of other mediating conditions, like anthropometric measures and inflammatory factors, is highly recommended.

\section{Declarations}

\section{Ethics approval and consent to participate}

This study was licensed by the Ethical Committee of Tehran University of Medical Sciences with the code of IR.TUMS.VCR.REC.1399.421.

\section{Consent for publication}

Not applicable

\section{Availability of data and materials}

All data generated or analyzed during this study are included in this published article.

\section{Competing interests}

The authors declare that there is no conflict of interest.

\section{Funding}

This research received no grant from any funding agency in the public, commercial, or not-for-profit sectors.

\section{Acknowledgment:}

This study was licensed by the Ethical Committee of Tehran University of Medical Sciences with the code of IR.TUMS.VCR.REC.1399.421.

\section{Reference}

1. Chan JF-W, Yuan S, Kok K-H, To KK-W, Chu H, Yang J, et al. (2020). A familial cluster of pneumonia associated with the 2019 novel coronavirus indicating person-to-person transmission: a study of a family cluster. The Lancet. 2020;395(10223):514-523.

2. Kuiken T, Fouchier RA, Schutten M, Rimmelzwaan GF, Van Amerongen G, Van Riel D, et al. (2003). Newly discovered coronavirus as the primary cause of severe acute respiratory syndrome. The Lancet. 2003;362(9380):263-270.

3. de Groot RJ, Baker SC, Baric RS, Brown CS, Drosten C, Enjuanes L, et al. (2013). Commentary: Middle east respiratory syndrome coronavirus (mers-cov): announcement of the coronavirus study group. Journal of virology. 2013;87(14):7790-7792.

4. WHO. Novel coronavirus - China. Jan 12, 2020.

5. Huang C, Wang Y, Li X, Ren L, Zhao J, Hu Y, et al. (2020). Clinical features of patients infected with 2019 novel coronavirus in Wuhan, China. The Lancet. 2020;395(10223):497-506.

6. Xu X-W, Wu X-X, Jiang X-G, Xu K-J, Ying L-J, Ma C-L, et al. (2020). Clinical findings in a group of patients infected with the 2019 novel coronavirus (SARS-Cov-2) outside of Wuhan, China: retrospective case series. $b m j$. 2020;368.

7. Grant WB, Lahore H, McDonnell SL, Baggerly CA, French CB, Aliano JL, et al. (2020). Evidence that vitamin D supplementation could reduce risk of influenza and COVID-19 infections and deaths. Nutrients. 2020;12(4):988.

8. Makoui RH, Dizaji MS, Khederlou H. (2018). Comparison of Serum Levels of Vitamin D in Patients With and Without Acute Coronary Syndrome. International Journal of Cardiovascular Practice. 2018;3(2):34-37.

9. Stumpf WE, Sar M, Reid FA, Tanaka Y, DeLuca HF. (1979). Target cells for 1, 25-dihydroxyvitamin D3 in intestinal tract, stomach, kidney, skin, pituitary, and parathyroid. Science. 1979;206(4423):1188-1190.

10. Pilz S, März W, Wellnitz B, Seelhorst U, Fahrleitner-Pammer A, Dimai HP, et al. (2008). Association of vitamin D deficiency with heart failure and sudden cardiac death in a large crosssectional study of patients referred for coronary angiography. The Journal of Clinical Endocrinology \& Metabolism. 2008;93(10):3927-3935.

11. Michos ED, Melamed ML. (2008). Vitamin D and cardiovascular disease risk. Current Opinion in Clinical Nutrition \& Metabolic Care. 2008;11(1):7-12.

12. Laird E, Rhodes J, Kenny RA. (2020). Vitamin D and inflammation: potential implications for severity of COVID-19. Ir Med J. 2020;113(5):81.

13. Ilie PC, Stefanescu S, Smith L. (2020). The role of vitamin D in the prevention of coronavirus disease 2019 infection and mortality. Aging Clinical and Experimental Research. 2020:14.

14. Pereira-Santos M, Santos JYGd, Carvalho GQ, Santos DBd, Oliveira AM. (2019). Epidemiology of vitamin D insufficiency and deficiency in a population in a sunny country: Geospatial meta-analysis in Brazil. Critical reviews in food science and nutrition. 2019;59(13):2102-2109. 
15. Holick MF. (2009). Vitamin D status: measurement, interpretation, and clinical application. Annals of epidemiology. 2009;19(2):73-78.

16. D'Avolio A, Avataneo V, Manca A, Cusato J, De Nicolò A, Lucchini R, et al. (2020). 25-hydroxyvitamin D concentrations are lower in patients with positive PCR for SARS-CoV-2. Nutrients. 2020;12(5):1359.

17. Panagiotou G, Tee SA, Ihsan Y, Athar W, Marchitelli G, Kelly D, et al. (2020). Low serum 25-hydroxyvitamin D (25 [OH] D) levels in patients hospitalized with COVID-19 are associated with greater disease severity. Clinical endocrinology. 2020.

18. Qi C, Li B, Guo S, Wei B, Shao C, Li J, et al. (2015). P-Selectinmediated adhesion between platelets and tumor cells promotes intestinal tumorigenesis in ApcMin/+ mice. International journal of biological sciences. 2015;11(6):679.

19. Greiller CL, Martineau AR. (2015). Modulation of the immune response to respiratory viruses by vitamin D. Nutrients. 2015;7(6):4240-4270.

20. Pike JW, Meyer MB, Lee S-M, Onal M, Benkusky NA. (2017). The vitamin D receptor: contemporary genomic approaches reveal new basic and translational insights. The Journal of Clinical Investigation. 2017;127(4):1146-1154.
21. Sathyamurthy I, Shyam P, Kirubakaran K, Srinivasan K, Jayanthi K. (2012). 25 Hydroxy vitamin D3 levels in acute coronary syndrome. journal of indian college of cardiology. 2012;2(4):141-143.

22. Lau FH, Majumder R, Torabi R, Saeg F, Hoffman R, Cirillo JD, et al. (2020). Vitamin D insufficiency is prevalent in severe COVID-19. medRxiv. 2020.

23. Cao Y, Liu X, Xiong L, Cai K. (2020). Imaging and clinical features of patients with 2019 novel coronavirus SARS-CoV-2: A systematic review and meta-analysis. Journal of medical virology. 2020.

24. Vaduganathan M, Vardeny O, Michel T, McMurray JJ, Pfeffer MA, Solomon SD. (2020). Renin-angiotensin-aldosterone system inhibitors in patients with Covid-19. New England Journal of Medicine. 2020;382(17):1653-1659.

25. Martineau AR, Jolliffe DA, Hooper RL, Greenberg L, Aloia JF, Bergman P, et al. (2017). Vitamin D supplementation to prevent acute respiratory tract infections: systematic review and metaanalysis of individual participant data. $b m j$. 2017;356.
This work is licensed under Creative Commons Attribution 4.0 License

To Submit Your Article Click Here:
Ready to submit your research? Choose Auctores and benefit from:

$>$ fast, convenient online submission

$>$ rigorous peer review by experienced research in your field

$>$ rapid publication on acceptance

$>$ authors retain copyrights

$>$ unique DOI for all articles

$>$ immediate, unrestricted online access

At Auctores, research is always in progress.

Learn more https://auctoresonline.org/journals/journal-of-thoracic-diseaseand-cardiothoracic-surgery- 